\title{
REGIONAL MODELS OF METAL PRODUCTION IN WESTERN ASIA IN THE CHALCOLITHIC, EARLY AND MIDDLE BRONZE AGES
}

\author{
MODELOS REGIONALES DE PRODUCCIÓN METALÚRGICA EN ASIA \\ OCCIDENTAL EN EL CALCOLÍTICO BRONCE ANTIGUO Y MEDIO
}

\author{
LIUDMILA AVILOVA (*)
}

\begin{abstract}
The objective of this work is the reconstruction and comparative analysis of regional models of metal production in the Chalcolithic, Early and Middle Bronze Ages. The work is based on the statistical analysis of unique computer database on archaeological metal finds from four regions of the Near East: Anatolia, Mesopotamia, the Levant, and Iran. The materials are analysed by four indicators: distribution by the chronological periods, artefacts' function, proportion of used metals and copper-based alloys. The author presents a series of conclusions concerning the preconditions for the beginnings of metal production in Western Asia and the pioneering role of Iran in its emergence, the important role the piedmont territories played in the development of metal production, the leap-like pattern of production dynamics shown by the periods, and its relation to the spread of a producing economy, long-distance exchange, and the emergence of the early civilizations.
\end{abstract}

\section{RESUMEN}

El objetivo de este trabajo es la reconstrucción y análisis comparativo de modelos regionales de producción metalúrgica del Calcolítico y la Edad del Bronce Inicial y Media. Se basa en el análisis estadístico de una base de datos única sobre hallazgos metálicos de cuatro regiones del Próximo Oriente: Anatolia, Mesopotamia, el Levante e Irán. Los materiales se analizan atendiendo a cuatro variables: periodos cronológicos, función de los artefactos, proporción de los metales usados y las distintas alea-

(*) Institute of Archaeology, Russian Academy of Sciences ul. Dm. Ulyanova 19, Moscow, Russia. Correo electrónico: aviloval@mail.ru.The work is supported by RFH, projects 06-01-00044a \& 07-01-00066a.

Recibido: 13-VI-2007; aceptado: 20-XII-2007. ciones del cobre. La autora aporta una serie de conclusiones respecto a las precondiciones para los inicios de la producción metalúrgica en el Oeste Asiático; sobre el papel pionero de Irán en su aparición; la importancia de los piedemontes en su desarrollo; el patrón no continuo que se observa en las dinámicas de producción por periodos; y su relación con la expansión de la economía de producción, el intercambio a larga distancia y la aparición de las primeras civilizaciones.

Key words: Metal production. Chalcolithic. Bronze Age. Western Asia. Computer database. Statistical analysis. Comparative study. Regional models. Metallurgical province.

Palabras clave: Producción metalúrgica. Calcolítico. Edad del Bronce. Asia occidental. Análisis estadístico. Estudio comparativo. Modelos regionales. Provincias metalúrgicas.

\section{INTRODUCTION}

The role metal played in cultural and social processes from the remote past was determined by the fact that it was one of the basic sorts of materials produced both for internal consumption and long-distance exchange.

Introduction of metals marked the epoch often termed as the Early Metal Period, which implies the Chalcolithic and the Bronze Age (the $5^{\text {th }}-2^{\text {nd }}$ millennia BC). This time was characterized by emergence of a new branch of economy, that is, metal producing and metalworking, closely related to such basic phenomena as the emergence of civilizations, intense interaction of human groups, spreading cultural and technological 
achievements over vast territories. Taken in this aspect, archaeometallurgical studies enable us to discuss a range of problems, among them: the development of early metallurgy and metalworking; spread of technological and other innovations; formation of social factors which paved the way for their adoption.

The issues concerning the early metal production recently have attracted serious scholarly interest. A series of investigations related to ancient metal production and functioning of metal in ancient societies have been launched by E.N. Chernykh in the Institute of Archaeology of the Russian Academy of Sciences (Avilova and Chernykh 1989; Avilova et al. 1999; Černyh et al. 1991; Chernykh 1992; Chernykh et al. 2002; Avilova 1996; Černykh and Avilova 1996; Avilova 2001; Avilova and Orlovskaya 2001; Avilova 2003; 2004a; 2004b; 2005).

Within the framework of these projects the concept of metallurgical provinces has been suggested (Chernykh 1971). A metallurgical province is viewed as a major production and historical/cultural system of the past comprising a number of related metallurgical and/or metalworking foci, limited in space and time (Chernykh 1992: 140-171). Functioning of these systems to a great extent determined the processes of production, social and cultural development of ancient societies, progress in mining, metallurgy and metalworking, working out technological and morphological standards. The concept well corresponds to the scientific trajectory aimed at reconstruction of the world systems of the past (Kohl 1987). It presupposes compiling specialized regional computer databases, which enables to investigate the above problems with application of modern methods to the mass archaeological material.

At present three basic zones have been outlined in Eurasia, each characterised by certain model of metal production (Chernykh et al 2002). These are:

1. Early civilisations of Western Asia;

2. Animal-breeding entities of the steppe and forest-steppe zone of Eurasia that played the role of a mediator in spread of new technologies;

3 . Conservative peripheral groups of the forest zone of Northern Eurasia.

The Circumpontic metallurgical province (CMP) was basic one in the spheres of production and culture in the Early and Middle Bronze Ages in the vast territory from the Balkans, southern part of Eastern Europe and the Caucasus to Anatolia, Mesopotamia, Western Iran and some other territories of Eastern Mediterranean and the Middle East. No doubt, development of regions so different geographically and culturally was marked by specific features reflected by metal production and use.

It might look unexpected of a Russian archaeologist to undertake a synthesising work based almost entirely on the data obtained from foreign publications. The main reason for it was an attempt to apply the concept of metallurgical provinces viewed as world systems to the materials known from the motherland of ancient civilisations. Methodically, it seems useful to check up the investigational methods worked out by the Russian specialists against the voluminous databases comprising impressive materials from the regions known as the source of the Old World relative and absolute chronologies. The author had also in mind that the emergence and development of metal production in this important zone to a greater or lesser extent influenced similar processes in the territory of present Russia.

Territorial scope of this work covers the zone where the earliest civilizations had emerged: Mesopotamia; Iran; Anatolia; Syria and Palestine (or the Levant). These regions were marked by close interaction in many fields of economic and cultural development and production in the Neolithic, Chalcolithic, and the Bronze Age. Thus, from this zone originate the earliest metal finds dating from the $9^{\text {th }}-6^{\text {th }}$ millennia BC. In this territory had emerged the early urban civilizations and state-type structures of the $4^{\text {th }}-3^{\text {rd }}$ millennia $\mathrm{BC}$. The current investigation is aimed at revealing and formulating basic characteristics of metal production in each of the four regions of Western Asia; as a result models of production dynamics are suggested constructed by means of the comparative analysis of specialised computer databases.

Chronological framework of the investigation covers three basic periods interpreted from the standpoint of the history of metal production. This historical-metallurgical chronological scheme is based both on cultural and metallurgical criteria (Chernykh et al. 2002: 83-84, Fig. 3). According to the system, the Chalcolithic generally corresponds to the Late Ubaid period (in calibrated radiocarbon dates 4500-3700 BC), 
EBA - to the Uruk period including Jamdet Nasr (3700-2700 BC), MBA - to Early Dynastic I-III, Akkad, the $3^{\text {rd }}$ dynasty of Ur, Hammurabi (2700-1800 BC). Table 1 shows positions the key sites of Anatolia, Mesopotamia, Iran and the Levant occupy in the system of relative chronology of Western Asia. This chronological scheme takes into account a series of publications devoted to the Near Eastern chronology (Mellaart 1981; Porada et al. 1992; Voigt and Dyson 1992).

Method. To carry out the comparative analysis of metal production within the four regions with application of a single method specialized computer databases were compiled. The databases are unique, as far as their extension and informativeness are concerned. They comprise rather detailed information on ancient metal artefacts. The DB structure consists of 53 indications describing each artefact; these include: site name, association, chronology, function, morphology, material (either marked indefinitely, as copper or bronze or including the results of spectral analysis, if available, that is, the data on concentration of 11 elements: $\mathrm{Sn}, \mathrm{Pb}, \mathrm{Zn}, \mathrm{Bi}, \mathrm{Ag}, \mathrm{Sb}$, $\mathrm{As}, \mathrm{Fe}, \mathrm{Ni}, \mathrm{Co}, \mathrm{Au}$ ); publication, and other (Chernykh et al. 1996: 95-103). Statistical analysis of DB provides us with reliable quantitative characteristics of mass production in given region and given chronological period, and thus enables to suggest comparable regional models of production dynamics and functioning of metals based on a single methodical approach.
Statistical analysis is carried out by the following indications:

1. Distribution of material by the chronological periods;

2. Distribution of finds according to their function (tools/weapons, ornaments and costume details, vessels, objects of religious character and social significance, blanks/ingots, casting moulds);

3. Share of different metals in production (copper and copper-based alloys, gold, silver, lead);

4. Formulas of copper-based alloys.

Characteristics of metal production and use are suggested within three broadly taken chronological periods - the Chalcolithic, the Early Bronze Age (EBA) and the Middle Bronze Age (MBA). The models of metal production are considered against the background of different stages of cultural, historical, social and economic development of the regions.

Natural resources. During the last decades archaeologists are more and more interested in the debris pointing to the processes of mining ores, smelting and/or melting metal. Mineral deposits are distributed in the discussed zone very irregularly. Three regions of the four considered ones (Anatolia, Iran, and the Levant) have cupriferous areas rich in native copper and copper ore deposits, both oxidic and sulphide. This contributed substantially to local population's acquaintance first with native copper and then melting copper of ores. With this development the use of

\begin{tabular}{|c|c|c|c|c|c|c|c|c|c|}
\hline Mesopotamia & Susa & Cent. Iran & NE Iran & Palestine & Byblos & Amuq & Anatolia & Caucasus & Periods \\
\hline & & & & & & & & & LBA \\
\hline & & & & & IX & $\mathrm{L}$ & Troy VI & & $1800 / 1700$ \\
\hline \multicolumn{10}{|l|}{ Hammurabi } \\
\hline Isin-Larsa & & & & & VIII & $\mathrm{K}$ & & & \\
\hline \multirow[t]{2}{*}{ 3rd Dyn. of Ur } & V B Acr.Ninhursag temple & & C & MBA & VII & & Kultepe & Trialeti & \\
\hline & VA & & Hissar III & & & & & & \\
\hline \multirow[t]{2}{*}{ Akkad } & IV B & & $\mathrm{B}$ & EBA/MBA & & $\mathrm{J}$ & Arslantepe VID & & MBA \\
\hline & & & & EBA 3 & & I & & & \\
\hline \multirow[t]{2}{*}{ ED III } & & & A & & & $\mathrm{H}$ & Alaca Royal Cem & Sachkhere & \\
\hline & IV A & & & EBA 2 & & & Troy III & Velikent & \\
\hline ED II & III C & & & & & G & Troy II & Bedeni & \\
\hline ED I & III B Acropole 14a-13 & & & EBA 1 & $\mathrm{VI}$ & & & Kura- & $2700 / 2500$ \\
\hline \multirow[t]{3}{*}{ Jamdat Nasr } & III A Acropole 16-14a & Sialk IV 2 & & & $\mathrm{~V}$ & $\mathrm{~F}$ & Troy I & Araxes & \\
\hline & & & Hissar IIB & Ghassul- & & & & Novosvobodnaya & EBA \\
\hline & & & & Beersheba & IV & & ArslantepeVIA & Mai- & \\
\hline Uruk & II Acropole 22-17 & Sialk IV 1 & & Chalcolithic & III & & Arslantepe VII & kop & $3700 / 3500$ \\
\hline Ubaid 4 & & Sialk III 6-7 & Hissar IC/IIA & & II & $\bar{E}$ & Beyce- & Tekhut & Chalco- \\
\hline Ubaid 3 & I Acropole 27-24 & & & & & & sultan $28-24$ & Kultepe & lithic \\
\hline \multicolumn{10}{|l|}{ Ubaid 2} \\
\hline Ubaid 1 & & Sialk III 4-5 & Hissar IA/B & & & D & & & 4500 \\
\hline
\end{tabular}

Table 1. Chronological sequences of basic sites in Western Asia. 
copper expanded dramatically, and the earliest independent centres of production and use of metal emerged.

In Eastern Anatolia of key importance were the Ergani Maden deposits, despite no traces of ancient mining have been discovered there so far (Jesus 1978). Close to it the famous settlement of Çayönü Tepesi dating from the pre-pottery Neolithic is situated, where a series of over 100 earliest copper artefacts have been excavated, which points to early exploitation of the local resources by the ancient population. Of special interest is the mining district Kozlu in Central Anatolia located not far from the royal cemetery of Horoztepe. In the first part of the $3^{\text {rd }}$ millennium BC local miners extracted sulphide copper ore from these mines (Giles and Kuijpers 1974).

In Iran mineral resources widely occur within the region, which provided favourable conditions for formation of independent foci of metal production (Pigott 1999). The deposits of Talmessi and Meskani (Anarak region) produced both native copper and arsenical copper, mostly with admixture of nickel. Ancient mines were investigated in Veshnoveh and reliably dated to the $4^{\text {th }}$ millennium BC. The traces of smelting copper of ores and melting in crucibles have been registered in a number of sites: copper slags in Sialk II and Shahr-i-Sokhta, slags and the remains of copper-smelting furnaces in Hissar II and Shahdad, casting workshop in Tepe Ghabristan. Generally, archaeological sites often form clusters situated in metalliferous zones.

Palestine also had rich sources of copper (Antikes Kupfer im Timna-Tal 1980). Abundant remains of mining and metallurgical activities have been investigated in Wadi Arabah situated between the Red and the Dead seas. Thus, in the regions of Timna and Feinan numerous and well preserved sites evidence copper ore mining and smelting, the earliest sites dating from the $4^{\text {th }}$ millennium BC. The region is a unique one, as far as the scale of ore extracting and copper smelting is concerned: the total amount of copper slag is estimated as 150-200 thousand tons. The local ore was represented by malachite and very rich in copper, up to $56 \% \mathrm{Cu}$.

Southern Mesopotamia had no mineral sources of her own, nonetheless, it was there that in the $4^{\text {th }}$ and $3^{\text {rd }}$ millennia $\mathrm{BC}$ a great urban civilization emerged and early states formed. In the $3^{\text {rd }}$ millennium $\mathrm{BC}$ impressive series of metal ob- jects are known from Mesopotamia. The Sumerian cuneiform texts mention various metals, sorts of metal, and alloy types, and indicate the lands from where different kinds of metal were procured. Many of them have been reliably identified. Thus, ancient copper-land of Magan and the shipping port of Dilmun were situated in the today Oman and Bahrein; metals were imported also from Anatolia and Iran (Moorey 1994). It is obvious that the Mesopotamian city-states had overcome this serious barrier in their development by organizing intense searching and transportation of metals. In Northern Mesopotamia situation was more favourable, since it was situated not far from cupriferous zones of Eastern Anatolia and Iran, numerous trade routes intersecting there.

Databases. The DB on Anatolia comprises information on 37017 metal finds from 62 archaeological sites, that on Mesopotamia - 14893 finds from 7 sites, that on the Levant - 5500 finds from 65 sites, that on Iran - 3286 finds from 13 sites. Totally 60696 finds from 147 sites are included in DB.

As for spectral analyses of copper-based objects, it totals 1672 analyses (Anatolia - 658, Iran - 518, the Levant - 279, Mesopotamia - 217).

The author does not intend simply to impress reader by these figures. It is clear that the more abundant material is accumulated, systematically arranged and analysed, the more reliable conclusions and reconstructions may be suggested. This is especially true of the situation when the entire corpus of information originates from publications only, not to mention that some works are already out-of date, the authors' views often disagree in many points, such as chronology, trajectories of cultural relations and patterns of social development. The voluminous DB may substantially balance the situation and enables avoiding major faults.

\section{Comparative analysis of the regional models of metal production.}

1. Distribution of material by the chronological periods is shown in Table 2A and the chart (Fig. 1). In Anatolia to the Chalcolithic 71 metal finds is attributed $(0.2 \%$ of the total), the EBA associations have yielded 360 finds (1\% of the total); from the MBA sites 36586 objects were registered, which makes up $99 \%$. 


\begin{tabular}{|c|c|c|c|c|c|c|c|c|c|c|}
\hline \multirow{3}{*}{$\begin{array}{l}2 \mathrm{a} \\
\text { Region }\end{array}$} & \multirow{3}{*}{$\begin{array}{c}\text { Total } \\
\text { number } \\
\text { of finds }\end{array}$} & \multicolumn{3}{|c|}{ Distribution of finds } & \multicolumn{6}{|c|}{ Distribution of functional classes of finds } \\
\hline & & \multirow{2}{*}{$\begin{array}{c}\text { Chalco- } \\
\text { lithic }\end{array}$} & \multirow[b]{2}{*}{ EBA } & \multirow[b]{2}{*}{ MBA } & \multicolumn{3}{|c|}{ Class 1. Tools and weapons } & \multicolumn{3}{|c|}{ Class 2. Ornaments } \\
\hline & & & & & Chalc. & EBA & $\overline{M B A}$ & Chalc. & EBA & $\overline{M B A}$ \\
\hline$\overline{\text { Anatolia }}$ & $37017(100)$ & $71(0.2)$ & $360(1)$ & $36586(99)$ & $28(39)$ & $145(40)$ & $1115(3)$ & $41(58)$ & $188(52)$ & $34999(96)$ \\
\hline Mesopotamia & $14893(100)$ & $6(0.04)$ & $580(4)$ & $14307(96)$ & $4(67)$ & $53(9)$ & $469(3)$ & $2(33)$ & $439(76)$ & $13434(94)$ \\
\hline Levant & $5500(100)$ & $4(0.07)$ & $701(13)$ & $4795(87)$ & $3(75)$ & $366(52)$ & $1313(27)$ & & $181(26)$ & $1990(42)$ \\
\hline Iran & $3286(100)$ & $160(5)$ & $952(29)$ & $2174(66)$ & $114(71)$ & $86(9)$ & $1105(51)$ & $34(22)$ & $846(89)$ & $750(34)$ \\
\hline
\end{tabular}

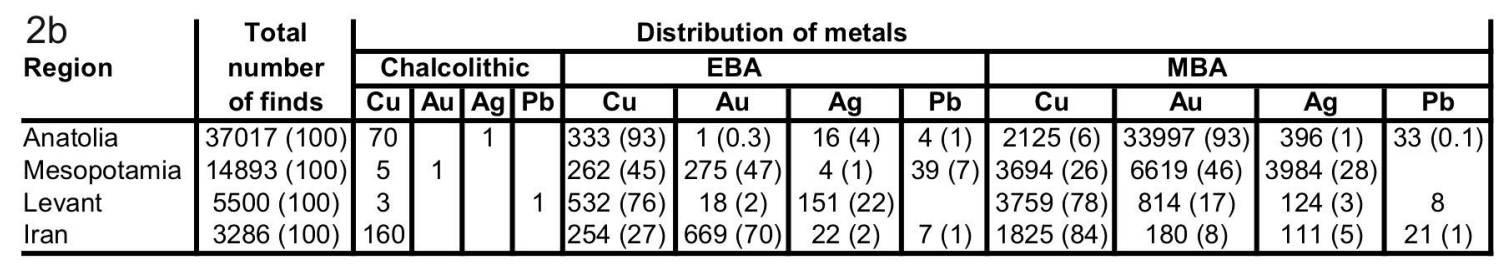

\begin{tabular}{|c|c|c|c|c|c|c|c|c|c|c|c|c|}
\hline \multirow{3}{*}{$\begin{array}{l}2 c \\
\text { Region }\end{array}$} & \multicolumn{12}{|c|}{ Distribution of copper and copper-based alloys } \\
\hline & \multicolumn{4}{|c|}{ Chalcolithic } & \multicolumn{4}{|c|}{$\overline{\text { EBA }}$} & \multicolumn{4}{|c|}{$\overline{M B A}$} \\
\hline & Totally an. & $\overline{\mathrm{Cu}}$ & Cu+As & $\mathrm{Cu}+\mathrm{Sn}$ & Totally an. & $\overline{\mathrm{Cu}}$ & $\mathrm{Cu}+\mathrm{As}$ & $\mathrm{Cu}+\mathrm{Sn}$ & Totally an. & $\overline{\mathrm{Cu}}$ & $\mathrm{Cu}+\mathrm{As}$ & $\mathrm{Cu}+\mathrm{Sn}$ \\
\hline$\overline{\text { Anatolia }}$ & $42(100)$ & $26(62)$ & $13(31)$ & $1(2)$ & $127(100)$ & $19(15)$ & $95(74)$ & $10(8)$ & $489(100)$ & $63(13)$ & $250(51)$ & $155(32)$ \\
\hline Mesopotamia & $3(100)$ & $3(100)$ & & & $85(100)$ & $12(14)$ & $63(74)$ & $7(8)$ & $129(100)$ & $21(16)$ & $49(38)$ & $58(45)$ \\
\hline Levant & 0 & & & & $90(100)$ & 35 (39) & $51(57)$ & $1(1)$ & 189 (100) & 39 (20) & $71(38)$ & 75 (39) \\
\hline Iran & $69(100)$ & $30(44)$ & $37(53)$ & & $76(100)$ & $22(29)$ & $53(70)$ & $1(1)$ & $373(100)$ & $5(1)$ & $258(69)$ & $102(28)$ \\
\hline
\end{tabular}

Table 2. Database on metal finds discussed in the article. Percentage is shown in brackets

In Mesopotamia the Chalcolithic is represented by 6 finds only $(0.04 \%$ of the total $)$, in EBA - 580 finds make up $4 \%$, in the MBA sites there were registered 14307 objects, or $96 \%$ of the corpus.

The Levantine Chalcolithic is represented by 4 finds $(0.1 \%$ of the total), from the EBA sites 701 artefacts originate $(13 \%)$, and from the MBA associations 4795 finds, or $87 \%$.

Iran: the Chalcolithic has yielded 160 metal objects ( $5 \%$ of the total), to EBA 952 finds are attributed $(29 \%)$, MBA is represented by 2174 finds $(66 \%)$.

Thus, in three regions (Anatolia, Mesopotamia, the Levant) metal production in the Chalcolithic is very limited, much less than $1 \%$ of the regional DB, and only in Iran this indication makes up $5 \%$.

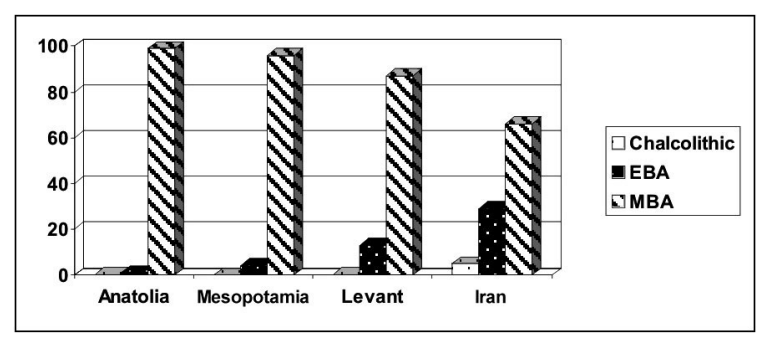

Fig. 1. Distribution of materials by regions and periods.
Transition to EBA differs in different regions. In the Levant and Mesopotamia there is a considerable rise of metal production, rather a leap forward: the total number of finds increases hundred-folds and even more. Anatolia and Iran look different way: in these regions production growth is not that sharp, 5 to 6 times as much.

Transition from EBA to MBA in Anatolia is marked by enormous leap forward: metal production increases almost hundred times as much. Mesopotamia also shows strong rise -25 times as much. In the two other regions this rate is not that big, 7 times as much in the Levant and only twice as much in Iran.

Generally, the most clearly expressed leap-forward-like dynamics in spread of metal objects is registered in Mesopotamia, both when transferring from the Chalcolithic to EBA and from EBA to MBA. On the contrary, Iran shows gradual smooth increase in metal production.

It is possible to establish certain correlation between the increase of quantity of metal objects by the regions not only with the availability of mineral resources, but also with the earliest tradition of shaping objects of metal. Thus, in Iran and Anatolia the first attempts of producing metal artefacts can be traced back to the pre-pottery Neolithic (the $9^{\text {th }}-7^{\text {th }}$ mill. BC). In Palestine usage of metal emerged later, in the Chalcolithic. In 
Mesopotamia situation is much more intriguing, since the country had no ore sources in her territory, and no early metal finds have been reported from it. Anyway, the quantity of metal objects rises steeply by the periods, especially during the transition from the Chalcolithic to EBA, which means that in EBA the Sumerian city-states had established a stable system of delivery of metal from the outside. This was possible under the condition of the Uruk urban civilisation with its developed system of trade relationships (Algaze 1989).

The sharp increase in metal production observed in MBA was also related to the pace of social development: in Mesopotamia and Anatolia royal cemeteries (Ur, Alaca Höyük, Horoztepe) have been excavated; in Anatolia rich treasures belonging to local dynasties have been discovered (Troy, Eskiyapar). In Palestine temple treasuries have been excavated in Byblos. No associations of that kind have been registered so far in Iran, though treasures and separate burials of social elite are known from Hissar Tepe III.

2. Functional classes of objects. The total corpus of the material has been divided into 9 classes according to the artefacts' function. Class 1 comprises tools and weapons, class 2 - ornaments and costume details, class 3 - horse harness details, class 4 - protective armour, class 5 - vessels, class 6 - objects of religious function and social status, class 7 - semi-finished objects, class 8 - negatives on casting moulds, class 9 - objects of unclear function and fragments. Most numerous and important are classes 1 and 2 (see Table 2A).

In the Chalcolithic in the most numerous Iranian DB (160 items) tools and weapons dominate (71\%), considerable number of heavy metal-consuming objects (flat and shaft-hole axes, hoes, mirrors) is its specific feature (Fig. 2). Ornaments make up $22 \%$ of the material. It is important that in this early period a series of semi-finished objects was identified (so-called long pins with characteristic bulb on their ends from Tepe Sialk III and Tepe Ghabristan, see: Avilova and Terekhova 2006). In Anatolia, on the contrary, personal ornaments constitute $58 \%$ of the total, while tools/weapons of simple shapes (awls, needles, knives, flat axes) make up around $39 \%$. In Mesopotamia and the Levant no assessment may be suggested, since the collections are too poor.

In EBA correlation of the two basic classes (tools/weapons and ornaments) is shown in
Fig. 3A. In EBA a number of new categories of metal objects was introduced (shaft-hole axes, tanged spearheads) (Fig. 4). Ornaments dominate over tools/weapons in three regions, which is most clear in Iran with $89 \%$ of ornaments and only $9 \%$ of tools/weapons. This pattern of distribution has emerged there due to the materials from the kurgan cemetery of Se Girdan near the Urmia Lake: the burials contained over 660 golden beads (Trifonov 2000). In Mesopotamia the picture looks very similarly, with $76 \%$ and $9 \%$ respectively. Here the decisive role is played by Northern Mesopotamia, namely, the Uruk necropolis of Tepe Gawra, which has yielded numerous golden beads, rosette-shape applications and so forth (Tobler 1950) (Fig. 4: 23-30). This indication stresses the similarity observed between the Iranian and Mesopotamian models and also shows their similarity with Maikop culture in the North Caucasus (Munchaev 1975) where thousands of ornaments (golden beads in particular) were accounted for (Piotrovsky 1996). A specific feature of Southern Mesopotamia is high proportion of metal (lead) vessels originating from the Ur cemetery of Jamdat Nasr period (Woolley 1955). The only region marked by domination of tools/weapons is the Levant (52\%). Another specific feature of this region is unusually high rate of the objects interpreted as the markers of social state and religion beliefs. I mean the elaborate "wands", "crowns" and other finds from the Nahal Mishmar treasure (Fig. 4: 36, 37, 42, 43) (Bar-Adon 1980); these make up $19 \%$ of the total.

The chronology of the treasure is to a certain extent debatable (Frangipane 1985: 216; Ryndina 1998: 25). The association comprising over 400 objects probably should not be dated back to a narrow chronological span. Obviously, it was formed during a long period of time. The objects' morphology is related to the chemical composition of metal, and points both to a substantial difference in their production traditions and chronology: thus, 14 flat axes cast of "pure" copper in single-side moulds, as well as pyriform maceheads should be considered reliably early (Shalev 1991; Tadmor et al. 1995: 119-122), but the objects of clearly ritual function (Fig. 4: 37, 43) shaped of complex alloys $\mathrm{Cu}+\mathrm{As}+\mathrm{Sb}$ in the elaborate technology of lost-wax casting probably are of later age. I mean the cylindrical maceheads with vertical rows of projections (Tadmor et al. 


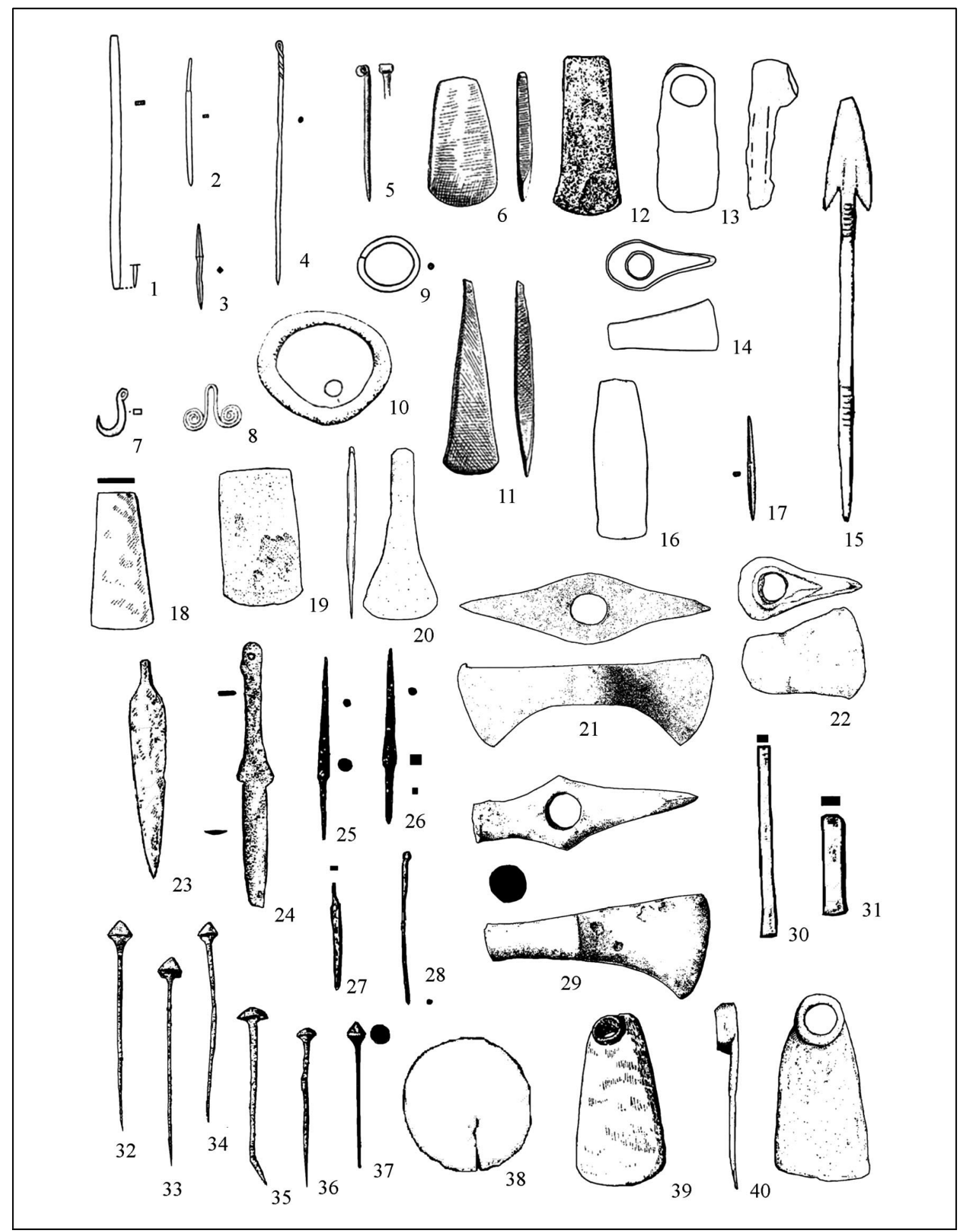

Fig. 2. Metal finds of in the Chalcolithic period (not to scale).

1-11 - Anatolia; 12-15 - Mesopotamia; 16, 17 - the Levant; 18-40 - Iran.

1-4, 9 - Beycesultan XXXIV; 5, 6, 11 - Mersin XVI; 7, 8, 10 - Ikiztepe II; 12 - Tepe Gawra XIII; 13 - Southern Mesopotamia, occasional find; 13 - Eredu; 15 - Ur, area W, burial G; 16 - Teleilat Ghassul; 17 - Amuq, $1^{\text {st }}$ mixed range; 18,23 , 25, 26-28, 30, 31 - Tepe Sialk III; 19-22, 29, 38, 40 - Susa I; 24, 32-37 - Tepe Hissar I. 9 - silver, the rest - copper/bronze. 


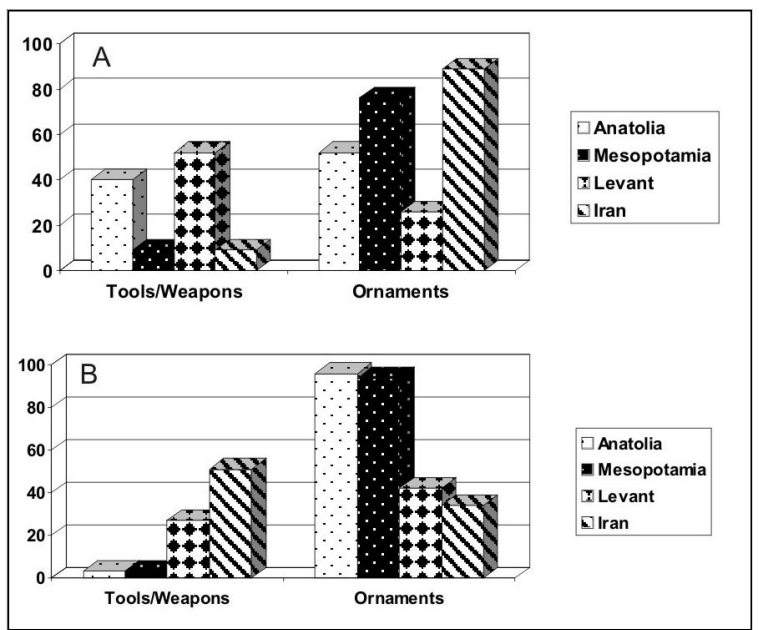

Fig. 3. Distribution of basic functional classes of metal objects in EBA and MBA.

A - Basic functional classes of metal objects in EBA; $\mathrm{B}-$ Basic functional classes of metal objects in MBA.

1995: 115, Fig. 9-10). Their counterparts (Tallon 1987: 130-131, Fig. 12) are known from EBA (Hissar II, Fig. 4: 45), and even ED III - Akkadian time, that is, MBA (Susa IV, the Royal cemetery of Ur - Fig. 5: 24, 48). The wide chronology of the treasure is confirmed by four $14 \mathrm{C}$ dates obtained from it that fall within the span from the mid $4^{\text {th }}$ to the mid $3^{\text {rd }}$ mill. BC (BarAdon 1980: 199), which well corresponds to the EBA of the historical-metallurgical scheme (Table 1). From the presented data it is clear that the metal production of the Southern Levant in the Uruk period needs further investigation, with special attention to the chronological aspect.

In MBA the morphology of finds extends substantially, in this period are introduced socketed spearheads, tanged arrowheads, various shapes of axes (those with hammered tubular socket, crescentic, anchor and fenestrated axes); wide range of metal vessels are used (Fig. 5), personal ornaments become immensely rich and varied (Fig. 6). Substantial shifts in the materials' distribution occur in the discussed period (Avilova 2005) (Table 2A; Fig. 3B). In Anatolia ornaments occupy dominating position (96\%, tools/weapons making up only $3 \%$ ), the same can be seen in Mesopotamia (94\% and $3 \%$ respectively). Ornaments prevail in the Levant also, though not so strongly (42\%); tools/weapons constitute a little more than the quarter of the total. Iran makes an exception, distribution of the two basic classes being quite different here: tools/weapons make up $51 \%$, and ornaments $34 \%$. In this aspect it should be taken into account that in the region in question no royal cemeteries yielding overwhelming concentration of ornaments are known, though burials of social elite have been investigated in Hissar III (Schmidt 1937).

Generally, in MBA maximal functional and morphological diversity of the repertoire of metal artefacts is registered: from 7 to 9 of all morphological classes possible are represented in each regional DB. Thus the distribution of the materials by the functional classes correlates with the chronological position of the associations and the type of archaeological site (settlement, cemetery, treasure).

3. Set of metals used (copper/bronze, gold, silver, lead) (Table 2B). In the Chalcolithic in all regions practically only objects made of copper/bronze are known, finds of other metals are exclusively rare. Thus, from Anatolia one silver object (a ring) is reported (Beycesultan XXXIV) (Fig. 2: 9), in Mesopotamia one find of golden foil was registered (Ur), in Northern Syria one object of lead originates from Amuq. The largest Chalcolithic collection from Iran comprises copper/bronze artefacts only.

In EBA essential differences can be observed in different regions (Avilova 2005) (Fig. 7A). In Anatolia the repertoire of metals practically remains the same as in the Chalcolithic: $93 \%$ of finds are made of copper/bronze. Quite different this aspect of distribution looks in two regions: in Iran, where gold ratio reaches $70 \%$, while copper/bronze makes up only $27 \%$ of the total; and in Mesopotamia, where gold ratio is $47 \%$, copper/bronze making up $45 \%$. I should stress that in the North Caucasus the EBA period is marked by quantitative domination of precious metals, mainly gold. The Levant shows less striking changes, copper/bronze remains basic metal $(76 \%)$, the most popular precious metal is silver $(22 \%)$.

MBA in three regions is marked by the most striking changes in use of metals (Fig. 7B). Thus, in Anatolia the situation is quite different from what we saw in EBA: now gold dominates absolutely $(93 \%)$. In Mesopotamia the trend to domination of precious metals already manifested in EBA strongly develops, gold now constitutes $46 \%$ and silver $28 \%$ of the total collection. Copper/bronze is on the third position, making up 


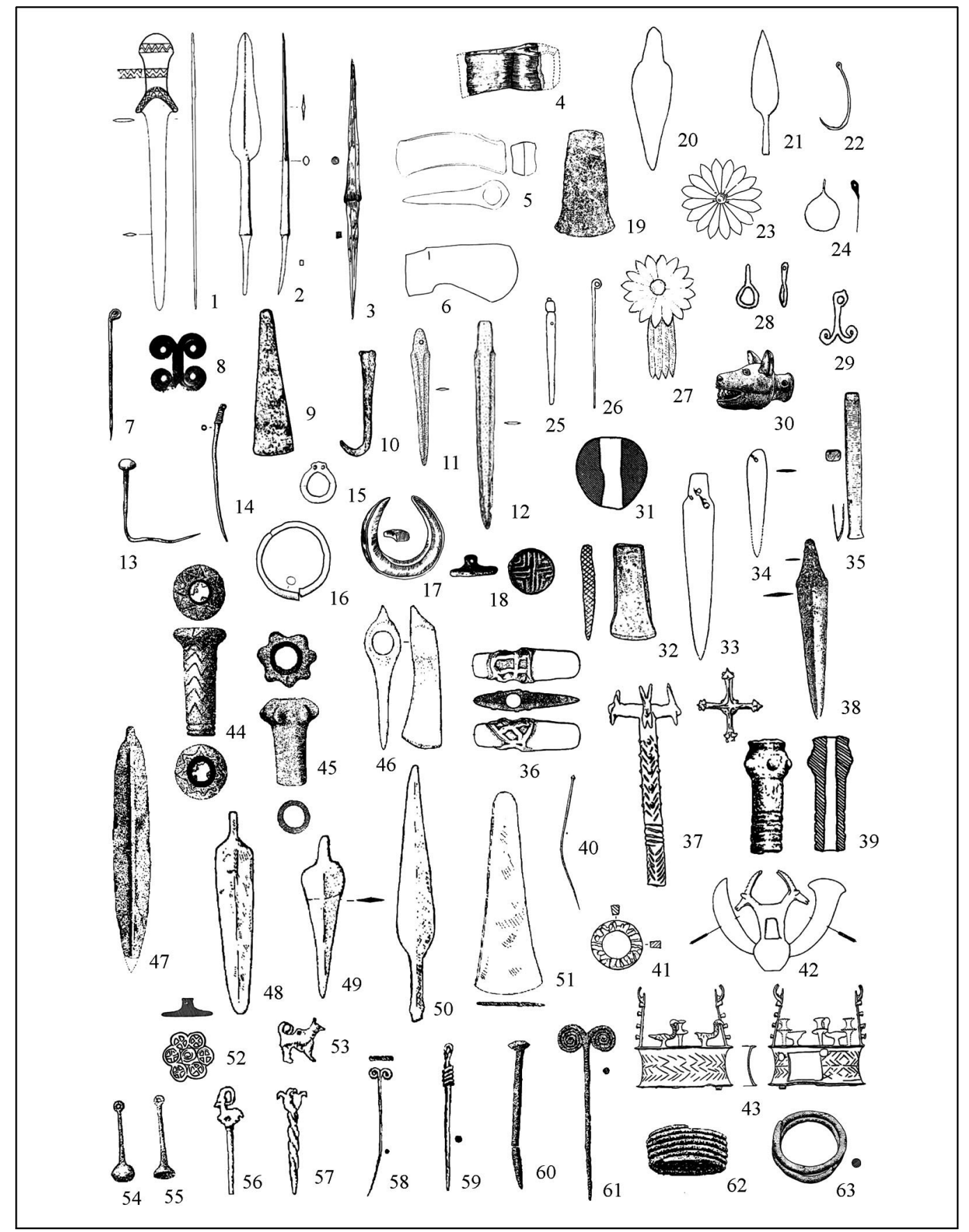

Fig. 4. Metal finds of the Early Bronze Age (not to scale).

1-18 - Anatolia; 19-30 - Mesopotamia; 31-43 - the Levant; 44-63 - Iran.

1, 2, 8 - Arslantepe VIA; 3, 4, 17 - Güzelova; 5 - Yusufeli; 6 - Merzifon; 7, 9, 13, 18 - Alishar Ia; 10 - Troy I; 11 - Beycesultan XVII; 12 - Beycesultan XVIII; 14 - Arslantepe VIB; 15, 16 - Ikiztepe I; 19 - Tepe Gawra XI; 23 - Tepe Gawra VIII-X; 24, 25 - Tepe Gawra VIII; 26 - Tepe Gawra VII; 27, 28, 30 - Tepe Gawra IX-X; 29 - Tepe Gawra XI; 20-22 - Ur, area F; 31, 36, 37, 42, 43 - Nahal Mishmar; 32 - Shiqmim; 33, 34 - Byblos; 35, 38, 40 - Amuq F; 39 - Abu Matar; 41 Nahal Qana; 44, 45, 47, 52, 54, 55, 60-63 - Tepe Hissar II; 46 - Se Girdan; 48, 51, 58, 59 - Tepe Sialk IV; 49, 50, 53, 56, 57 - Susa II - IIIA.

1 - bronze with silver inlays, 15, 23, 24, 27-29, 41, 53 - gold, 30 - electrum, the rest - copper/bronze. 


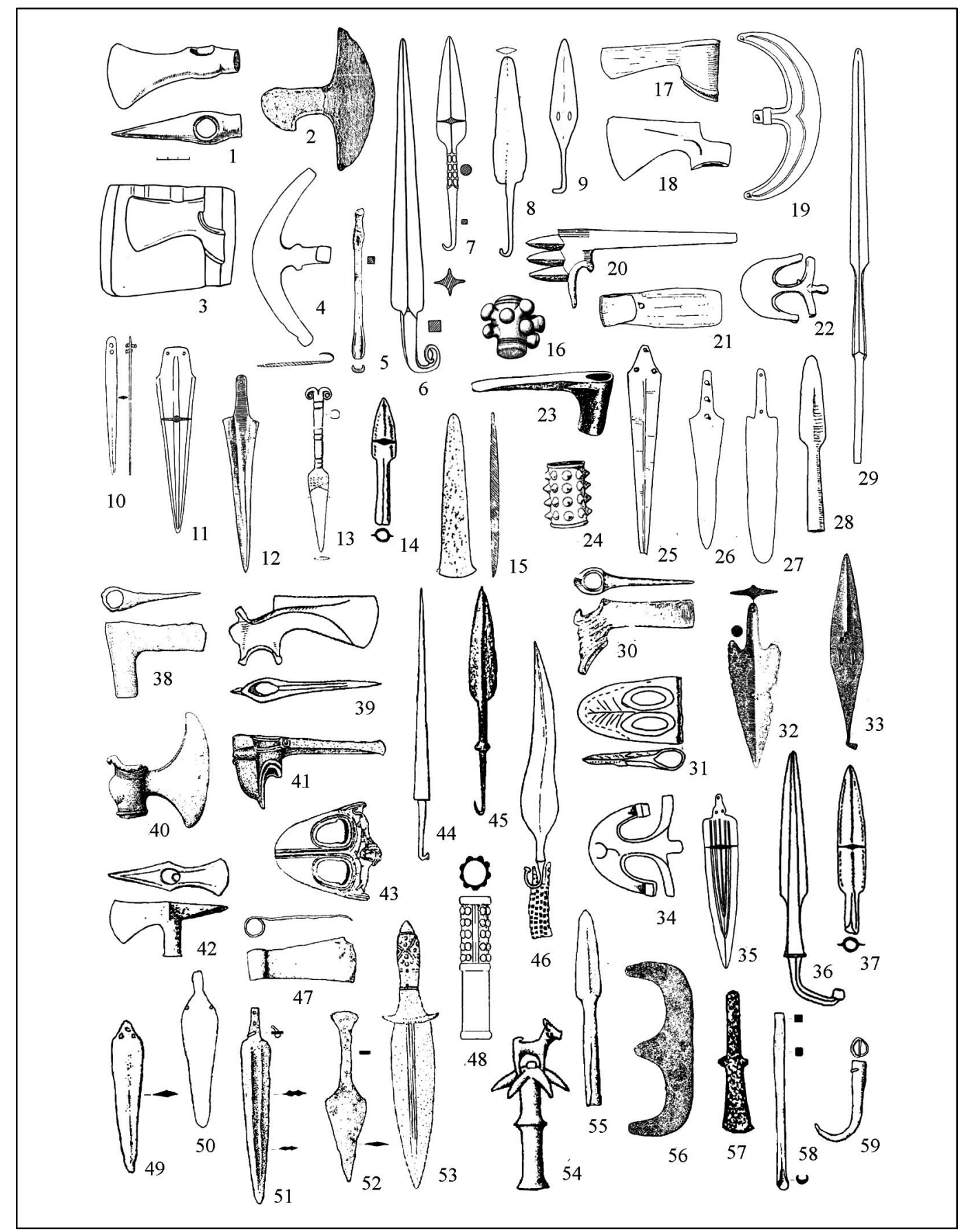

Fig. 5. Metal finds of the Middle Bronze Age (not to scale).

1-16 - Anatolia; 17-29 - Mesopotamia; 30-37 - the Levant; 38-59 - Iran.

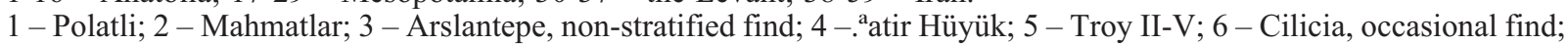
7 - Tarsus vicinity, occasional find; 8, 13 - Ikiztepe I; 9, 15 - Troy II, treasure A; 10 - Iasos; 11 - Bayindirköy; 12 - Soli; 14 - Kültepe Ib; 16 - Alaca Höyük; 17, 19, 24, 26, 29 - Ur (Early Dynastic III); 18, 23, 27 - Tepe Gawra VI; 20 - Ur (Akkadian); 21, 25, 28 - Ur (Early Dynastic III - Akkadian); 22 - Ur (Akkadian - $3^{\text {rd }}$ dynasty); 30 - Amuq J; 31 - Ain es-Samieh; 32 - Amuq H; 33 - Amuq, $2^{\text {nd }}$ mixed range; 34 - Byblos; 35, 37 - Megiddo; 36 - Ras Shamra; 38, 40, 47-49, 51, 52, 55, 56, 58, 59 - Susa IV - V; 39, 41, 43, 53 - Luristan; 42, 44, 46, 54 - Tepe Hissar III; 45, 57 - Tureng Tepe II; 50 - Geoy Tepe D. 


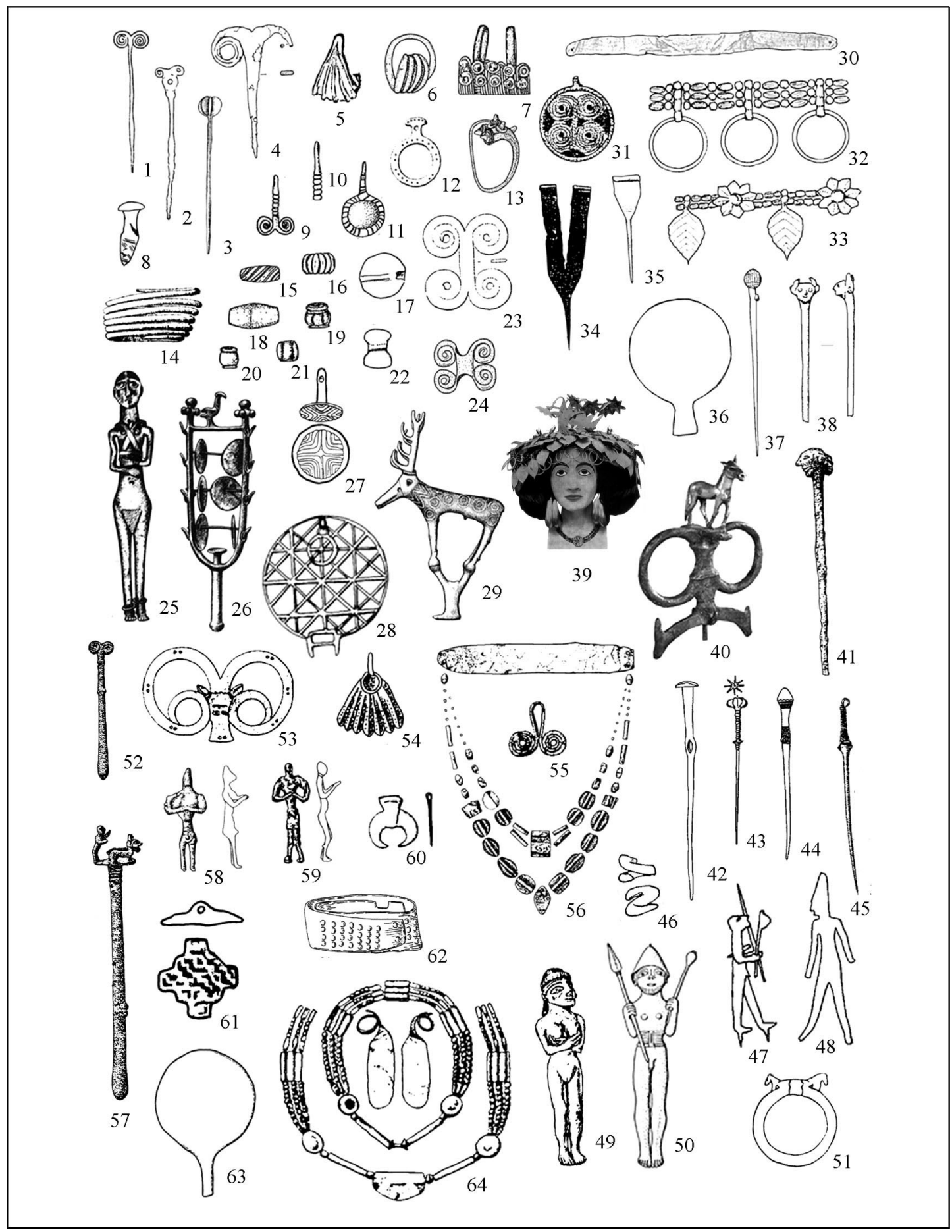

Fig. 6. Metal ornaments and symbolic objects of the Middle Bronze Age (not to scale). 1-19 - Anatolia; 30-41 - Mesopotamia; 42-51 - the Levant; 52-64 - Iran.

1 - Troy II; 2 - Alishar II; 3, 28, 29 - Alaca Höyük; 4 - Tilkitepe; 5 - Tarsus; 6, 7, 9-11, 13-16, 18-22, 24 - Eskiyapar; 8,

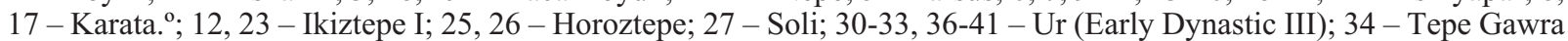
VI; 42, 44, 47, 48 - Byblos; 43 - Amuq J; 45 - Amuq H; 46 - Qatna; 49, 50 - Amuq G; 51 - Tell Ahmar (Til Barsib); 52, 53, 55-64 - Tepe Hissar III; 54 - Susa V.

3, 5-11, 13-22, 24, 30, 32, 33, 53-55, 64 - gold; 12 - lead, 31 - silver, lapis-lazuli; 35, 56 - silver. 


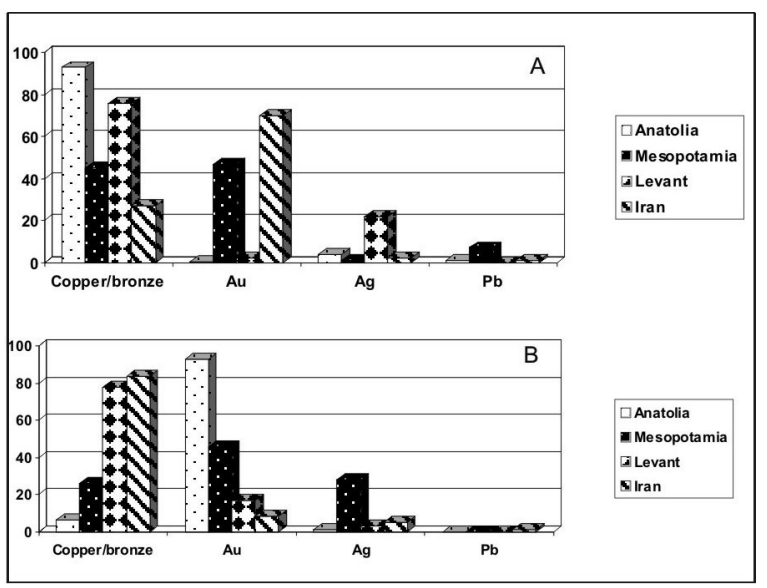

Fig. 7. Distribution of metals in EBA and MBA.

A - Distribution of metals in EBA; B - Distribution of metals in MBA.

$26 \%$ only. In Iran the general picture differs cardinally from that in EBA, now copper/bronze dominates $(84 \%)$, while the ratio of precious metals drops to $13 \%$. Only in the Levant the distribution of metals remains unchanged, the total mass of precious metals reaching $20 \%$, copper/bronze being basic material.

Generally, distribution of precious metals clearly correlates with mass production of ornaments discovered in burials of social elite and treasures.

It seems of interest to try to establish if there existed any correlation between mass production of ornaments, the use of precious metals, and availability of their sources. In Anatolia and Iran the situation looks rather balanced due to the both regions' rich mineral resources, Panning of alluvial gold from rather numerous sources was widely spread in antiquity. Thus, gold is panned even now in the rivers Djeihan and Sejhan in Cilicia - the region closely related with Mesopotamia and Syria. Gold-bearing rivers are mentioned in the Bible (Gen. II: 11,12). Extraction of rift gold was also known. The Sumerian and Akkadian texts mention as the sources of gold the land of Meluhha on the Gulf shores, and the mountainous land of Aratta located by many investigators to the East from Mesopotamia; more difficult to determine are the mountainous regions of Hahhum and $\mathrm{Su}$ (evidently, situated on the Upper Euphrates and Western Iran respectively) (Moorey 1994: 220).

When discussing the relationship between the mass production of golden objects and the sources of gold, Mesopotamia is worth special attention, because it was here that high rate of artefacts made of noble metals is observed (see Table 2B, Fig. 7A, B), despite the lack of gold and silver deposits. The overwhelming number of golden ornaments in the Se Girdan EBA burials in Western Iran and the MBA Anatolian treasures is not a surprise, taking into account the regions' rich mineral resources, gold and silver in particular. But in the Mesopotamian EBA from Tepe Gawra only 6 tools are known, while ornaments in the burials are strikingly numerous (275 ones, 262 of them made of gold). The site is situated on an important cross-road, so it is clear that the noble metals were transported there. As for MBA, only 63 metal finds originate from the habitation levels, tools/weapons (24 finds) and ornaments (25 ones) are represented in the same proportion, only 2 golden ornaments being accounted for. Since burials of this period are not known, it is impossible to say if Tepe Gawra was still included into the system of trade in gold.

In Southern Mesopotamia the situation looks quite different. In the Ur cemetery of Jamdat Nasr period (EBA) 84 metal finds are registered, 66 of them are metal vessels (38 lead ones), and 13 ornaments only, 4 of them are silver earrings; gold is not represented. Distribution of finds in the Royal cemetery of $\mathrm{Ur}$ in MBA is shown in Table 3.

Thus we can see that the ornaments made of noble metals taken together are four times more numerous than copper/bronze ones. This means that it was not simply the access to the sources of gold and silver that determined the mass production and use of ornaments made of noble metals. The example of Mesopotamia proves that the organised system of procurement of metals from beyond, gold and silver in particular, was equally, if not more substantial.

4. Copper-based alloys' formulas (Table 2C). From the Chalcolithic two representative selections of spectral analyses are available - 42 analyses from Anatolia and 69 from Iran. It is of importance that as early as the Chalcolithic in these regions metallurgically "pure" copper with no deliberate admixture was not basic material. From Fig. 8A it is clear that "pure" copper makes up $62 \%$ in Anatolia and less than a half of the total in Iran (44\%). Copper-arsenic alloy (often with admixture of nickel) is in the second position in Anatolia $(31 \%)$ and in Iran even in the first, reaching $53 \%$ of the total. 


\begin{tabular}{|l|r|r|r|r|}
\hline \multicolumn{1}{|c|}{ Classes of metal finds } & Totally & Copper/bronze & Gold & Silver \\
\hline 1 - tools/weapons & 189 & 189 & & \\
2 - ornaments & 13600 & 2600 & 6550 & 3850 \\
- harness details & 6 & 4 & 1 & 1 \\
4 - protective armour & 5 & 2 & 20 & 7 \\
5 - vessels & 200 & 110 & 35 & 20 \\
6 - symbolic objects & 80 & 25 & & \\
7 - semi-finished objects & 15 & 1 & & \\
- unclear objects & 15 & & \\
\hline
\end{tabular}

Table 3. Distribution of MBA finds from Royal cemetery of Ur by functional classes and metals.

Since the problem of natural or deliberate origin of arsenic in copper-based alloys remains highly debatable, it seems to be improper to try to discriminate between natural arsenical copper and man-made copper-arsenic alloys in the early period (see: Maddin et al. 1980; Gale et al. 1985). Mass analyses performed in the Laboratory of natural sciences of the Institute of Archaeology, RAS have revealed that statistical groups of material show dependence of arsenic content from objects' function; thus, ornaments usually contain up to $20 \%$ As, whilst tools/weapons have around $5 \%$ As (Chernykh 1966: 43; Eaton and McKerrel 1976: 175). Noteworthy, already in the Chalcolithic copper-arsenic alloys are widely used in Iran and Anatolia, the problem of their natural or deliberate character left aside.

Of EBA general domination of arsenic-copper alloys is typical (57-74 \%) (Avilova et al. 1999), together with total decrease of "pure" copper $(29 \%$ in Iran, $14 \%$ and $15 \%$ in Mesopotamia and Anatolia respectively) (Fig. 8B). The highest ratio of "pure" copper is registered in the Levant (39\%), which might be probably related to exploitation of rich ores of Timna and Feinan at that time. Chemical formulas of Mesopotamian and Iranian bronzes have a specific feature in common, namely, around a half of the total analysed materials show high nickel content (over $0.3 \%$ ). Presence of nickel is generally typical of certain ore sources, such as Talmessi-Meskani in Iran (Pigott 1999: 111-112) and the Omani ores (Pernicka 1995).

Nickel admixture was established also in the Maikop bronzes over a century ago (Virchow 1891) and then confirmed by mass analytical investigations (Chernykh 1966: 38-39). This proves that the relations maintained in EBA by the regions in question were not limited to morphological similarity and wide-scale use of gold, but covered also exploitation (probably, deliberate choice) of ores with certain properties.

EBA sees introduction of the earliest tin bronzes, even triple alloys $\mathrm{Cu}+\mathrm{Sn}+\mathrm{As}$. This evidences experimental search of new alloys and the initial stage of exploitation of new kinds of ores (cassiterite, stannite) and ore deposits.

In MBA further decrease of "pure" copper ratio is registered in Iran (only $1 \%$ of the total) and the Levant $(20 \%)$ (Fig.8 C). In Anatolia and Mesopotamia it plays a limited role, similar to what it was like in the preceding period. As far as

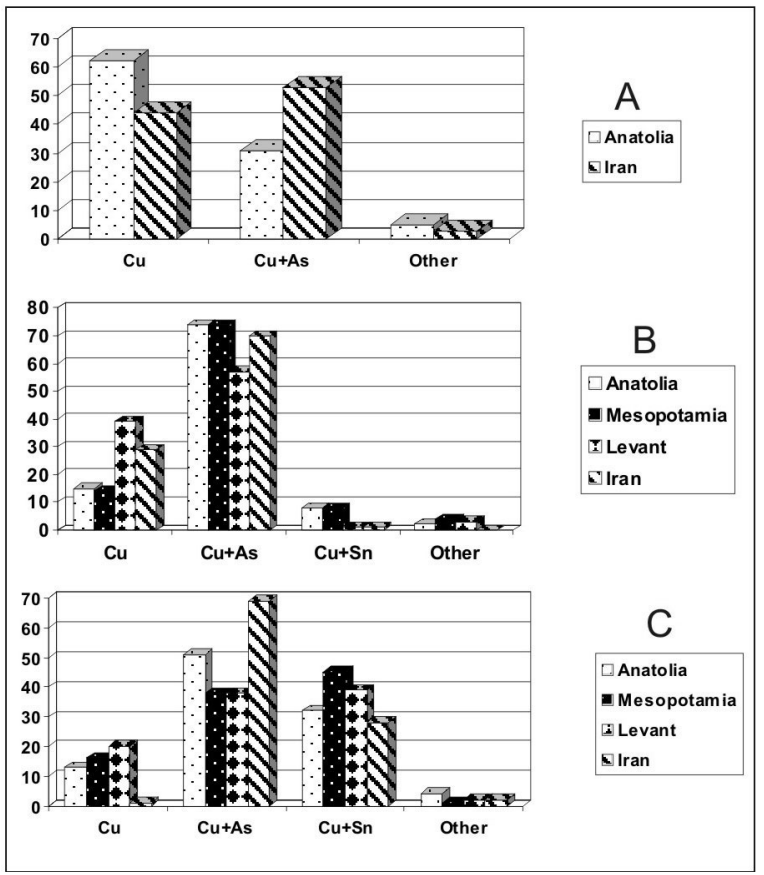

Fig. 8. Distribution of "pure" copper and copper-based alloys in the Chalcolithic, EBA and MBA.

A - "Pure" copper and copper-based alloys in the Chalcolithic; B - "Pure" copper and copper-based alloys in EBA; $\mathrm{C}$ - "Pure" copper and copper-based alloys in MBA. 
copper-arsenic alloys are concerned, in three regions their ratio decreases (38-51\%), and only in Iran they are produced on a large scale $-69 \%$. Like the EBA production, around a half of arsenical bronzes from Mesopotamia and their major part in Iran show high nickel content.

The feature uniting all the regions within the considered zone in MBA is wide use of tin bronzes, including triple alloys $\mathrm{Cu}+\mathrm{As}+\mathrm{Sn}$. This indication reaches $28 \%$ in Iran. In Mesopotamia tin bronzes dominate $(45 \%)$, which is similar to the data of the Pennsylvania project (Tadmor et al. 1995: 142). It is absolutely clear that in the period in question a system of tin procurement functioned; geologically, most probably from the territory of Afghanistan. This thesis is often met with in publications, despite at present no reliable information on ancient exploitation of tin deposits in Afghanistan exists. Tin sources are mentioned in Sumerian texts of the $3^{\text {rd }}$ mill. BC, and some of them have been identified on the Gulf shores (Moorey 1994: 298-300). Tin was delivered from the lands of Dilmun, Magan, Meluhha and Aratta, including the "tin mountains" situated, according to some scholars, eastwards from Mesopotamia.

Traces of extracting tin-containing ores are also known from Kestel (the Bolkardag Mountains, Turkey); the mines date from EBA III (MBA in the historical-metallurgical scheme); close to them there is the Göltepe settlement with the remains of ore processing and melting, as well as metal casting (Yener and Özbal 1987). But since the local ores are of polimetallic character, the deposits are thought to have been used as a source of gold, or silver and lead, but not tin (Muhly 1991). The difference in positions on the point is explained by the fact that no tin sources with the traces of ancient works may be reliably pointed to now in Western Asia.

In this aspect of great interest is the information published on the problem concerning tin deposits in Central Asia with the traces of ancient mining (Potts 1997: 170). The recent joint investigations of the German Archaeological Institute, archaeometallurgical group in Freiburg, the German Museum of mining in Bochum and the Institutes of Archaeology in Uzbekistan and Tajikis$\tan$ have revealed two significant deposits of tin ores in the Zeravshan valley. The pottery discovered near the mines of Karnab, Lapas, Changalli and Mushiston and the series of $14 \mathrm{C}$ dates sug- gest the period from the Late MBA to the Early Iron Age (1800-800 BC) as the chronology of their functioning. Settlements of miners located nearby are attributed to Andronovo culture (Parzinger and Boroffka 2003). J. Cierny supposes that both the settlements, mines and metal-smelting workshops investigated in the Kyzylkums and also attributed to Andronovo cultural unity not only produced metal for local market, but also could have exported it to the agricultural communities in Iran and/or Mesopotamia (Cierny 2002: 77-78). The interrelations between Bactria and Iran are well evidenced by morphologically representative finds starting from the $3^{\text {rd }}$ mill. BC. I mean the shaft-hole axes decorated with zoomorphic motifs and compartment stamp-seals (Tallon 1987: Nos. 72, 73, 1249, 1250; Yule 1982: Fig. 9c, 4) (Fig. 6: 61). We know also about the ancient system of trade in the Badakhshan lapis lazuli (Herrmann 1968) and the turquoise obtained in the Kyzylkums (Tosi 1974). This network of exchange could have been used also for procurement of tin to Iran and to Mesopotamia via Iran.

\section{CONCLUSIONS}

The most important feature of the early metal production in Western Asia is its extremely early origin. In the discussed zone there existed two basic preconditions for discovery of native copper, its melting and smelting copper ores to metal: natural ore deposits and advanced tradition of pyrotechnology, worked out in the course of producing lime and gypsum plasters. It is not an accident these zones overlap essentially (Pernicka 1995: Figs. 8, 9).

Production of metal objects started in the Chalcolithic in the second part of the $5^{\text {th }}$ mill. BC in Iran and, to a lesser extent, in Anatolia. The Chalcolithic collections of metal artefacts from Iran, on the one hand, and Ubaid sites in Mesopotamia, on the other hand, show sharp contrast (Amiet 1986: 36), as far as their quantitative and morphological characteristics are concerned. Evidently, the phenomenon of emergence of metal production in Iran depended on its rich mineral resources and developed exchange between $\mathrm{Me}-$ sopotamian agricultural civilization and the population of the Iranian plateau and Zargos Mountains. Such phenomena as development of irrigation system, formation of two-level settle- 
ment system, emergence of social structures of chiefdom type, and organised long-distance exchange (Antonova 1998: 71-72) developed against the background of rapidly growing need in metals. The scale of the Chalcolithic metal production in Iran looks even more striking, when comparing the state of archaeological researches in Mesopotamia and quite insufficiently studied territory of Iran (Avilova 2004b). It may be supposed that the advanced production modes and technological innovations emerged in the territory of Iran in the Ubaid period; then they were adopted and developed by the Mesopotamian city-states (Pigott 1999: 107, 118). Taking this into account, the old model of cultural development in Western Asia centred on Mesopotamia needs much new detailed considerations.

The role of piedmont territories in development of exchange network should be specially stressed. As N.I. Vavilov has shown, the earliest farming had emerged not in highly fertile alluvial valleys, but in the piedmont zones, where wild ancestors of domesticated cereals naturally grow, and the conditions are favourable for seasonal irrigation (Vavilov 1987). It seems of special significance that from this zone come the earliest metal finds dating back from the $9^{\text {th }}-7^{\text {th }}$ mill. BC (Çayönü Tepesi, Hallan Çemi, Aşikli Höyük, Nevali Çori, Can Hasan, Çatal Höyük in Anatolia, Ali Kosh, Shanidar, Tepe Sialk in Iran, Tell Ramad in Palestine, Tell Magzalia, Yarim Tepe I in Iraq). The piedmont regions have also yielded the most spectacular associations of metal objects of the Ubaid time (Susa I), and the Uruk period (necropolis of Tepe Gawra in Northern Mesopotamia, the Arslantepe VIA treasure in Eastern Anatolia, and the Maikop finds in the North Caucasus).

It seems that archaeologists and cultural anthropologists should pay special attention to the qualitative leap forward in metal production that marked the coming of EBA, and its relation to the processes of urbanisation and formation of early state systems. Of great significance in this aspect is the Uruk "temple economy" based on the centralised control over production and consuming, which allowed accumulation of grate amount of goods for exchange (Özdogan 2002). The farming civilization of the alluvium in this period forms a complicated system with the population of the Iranian and Anatolian plateaus that develops the complex economy of which metal pro- duction is an important component. The Sumerian society strongly feels lack of metals; its elite purposefully establishes and develops permanent intense contacts with the centres of metal production and metalworking located in the adjacent territories of Iran, Eastern Anatolia, and the Gulf.

Need for metal in the agricultural societies and necessity of certain agricultural products in stockbreeding communities were powerful catalysts for economic progress and development of social complexity. Special role in the interaction of farming communities with the mountaineers engaged in animal-breeding and metal production played agricultural goods (cereals, melted butter and oils) and craft products (textiles). In the depths of farming societies there were worked out such intellectual attainments as writing, sets of figurative motifs, finally, fashions, including costume and hair-styles that were important as the indications of social status.

This scheme of relationships with neighbours was developed by Egypt and Mesopotamia - the Old World's greatest producers of foodstuffs. In their lands high crop capacity of the fields allowed accumulating strategic stocks used in particular for exchange and accompanied by widescale spreading of various cultural standards. It should be pointed out that high crops in alluvium were not secure at all: repeated draughts were a permanent threat, while irregular floods destroyed crops. These factors in the situation of high population growth were of key significance for formation of basic characteristic features of the Mesopotamian civilization: urban centres residence of elite and bureaucracy; centralised control of production in general, and agricultural works in particular; control of irrigation system; rationing daily consuming with the objective to amass food supplies for lean years and organised trade. The supplies kept in the temple granaries could have been used also to support the power of ruling group and to form numerous armed detachments. Non-guaranteed success of farming paved the way for rivalry and militarization of policy implemented by the South Mesopotamian city-states; the impressive series of metal weapons from the Ur and Kish cemeteries of the Early Dynastic periods are eloquent evidences of the terminal phase of this process. It seems highly probable that growth of urban population and risk of local bad harvests were among the reasons that forced the Uruk communities to or- 
ganise long-distance trade expeditions, and to set up colonies far beyond the borders of the alluvial plain.

The lack of mineral resources in Southern Mesopotamia stimulated intensification of longdistance exchange and, thereby, extensive mining and smelting metals and search of highly valued exotic materials, including timber, copper, copper-based alloys and precious metals, stone for construction, and semi-precious stones in the regions rich in such resources. The general scheme of development of exchange relationships must have looked a kind of geometric series rather than arithmetical progression.

By impressively intense exchange is marked the turning point in the history of the Near East the Uruk period. The early polities pursue widescale temple constructing, consequently, they strongly feel the necessity of imported materials; the social elite closely related to the temple farming was the organiser of the exchange system. The role temples played in the extensive network of trade relations in the Uruk period can hardly be overestimated (Özdogan 2002: 68). Noteworthy, the Sumerians themselves conceived the raw materials (including metals) exchange as the activity performed with the purpose to construct and decorate temples. A colourful narration on this subject can be found in the epic "Enmerkar and the Lord of Aratta".

Thus, it is not an accident that the Uruk colonies (Arslantepe, Norşuntepe, Tepecik) are rather densely distributed in the regions with rich mineral resources, such as the Upper Euphrates. Great demand of the Mesopotamian civilization for metals permanently stimulated its production and social development of the population of the Iranian and Anatolian plateaus and the Gulf shores. Western and North-Western Iran, Eastern Anatolia and Mesopotamia constituted in EBA a single complex system. There must have appeared groups of professional craftsmen, their production could have circulated both in the shape of ingots and finished objects, which stimulated working out certain morphological and technological standards that functioned within the zone of the Uruk civilisation proper and the vast area stretched from the North Caucasus to the Levant, to one or other extent influenced by this civilisation.

Substantial growth of metal production in EBA is accompanied by their functioning as grave goods, which points to the important role metal played in that period as an indication of social status and prestige. In this aspect noteworthy are the golden ring-shaped ingots from the Nahal Qana burial association; their standard shape and weight presuppose advanced exchange relationships.

The comparison of metal production in the four regions of Western Asia in EBA evidences consolidation of Northern Mesopotamia, Eastern Anatolia, West and Central Iran, the North Caucasus and, to a certain extent, Syria and Palestine in a single cultural zone (Andreeva 1979; Trifonov 1987) marked by a single tradition of metal production. Most probably, North Mesopotamian and West Iranian cultural and production traditions penetrated to the North Caucasus along the Zagros foothills via the zone of the Lake Urmia and Eastern Daghestan.

The models of metal production in Anatolia and Mesopotamia show most close similarity: they are typified by clearly leap-forward-like dynamics in the use of metals while transition from one period to another, which is closely related to the impact the Mesopotamian city-states exerted on their western neighbours beginning from the Uruk period onward. In the Levant this pattern is manifested less clearly. On the contrary, the Iranian model of early metal production shows gradual development with permanent increase of production marked by some conservative features, such as the leading role of copper-arsenic alloys during all three chronological periods. Apparently, widely spread deposits of "pure" and arsenical copper hampered in some way wide introduction of tin bronzes in this region. The agricultural civilisation of Mesopotamia had successfully overcome such a critical obstacle in its development as lack of mineral resources through organization of their wide-scale supply from beyond in exchange for food staffs.

In MBA metal production was determined by interaction of early states: the Early Dynastic polities in Southern Mesopotamia, early state formations in Anatolia, later the Akkadian power in Northern Mesopotamia, the Elamite centres in South-Western Iran. In all these regions such phenomena are clearly expressed, as social stratification (burials of social elite), urban architecture with the monumental constructions of specific social functions and religious character (temples, palaces), treasures (including precious and sym- 
bolic objects). Morphology of metal artefacts is now marked by specifically local features. The single cultural and production zone did not exist in this period any longer, despite vivid contacts between the regions, including distant ones can be observed (from Anatolia, Syria and Palestine in the west via Mesopotamia and Iran as far north-east as Central Asia). But the North Caucasian connections have ceased, and this region follows its own way of strictly local independent development.

These are briefly presented results of the statistical work with computer DB on archaeological metal objects. They show the similarities and dissimilarities in metal production considered within the four regions of Western Asia, and reveal the dynamics of their interaction in this field during the Chalcolithic, EBA and MBA.

\section{BIBLIOGRAPHY}

ALGAZE, G. 1989: “The Uruk expansion: cross-cultural exchange in early Mesopotamian civilization". Current Anthropology 30: 571-608.

AMIET, P. 1986: L'âge des échanges inter-iraniens 3500-1700 a J.C. Ministere de la culture et de la communication. Paris.

ANDREEVA, M.V. 1979: "Ob izobrazheniyakh na serebryanykh maikopskikh sosudakh". Sovetskaya Arkheologiya 1: 22-34.

ANTIKES KUPFER IM TIMNA-TAL 1980: Antikes Kupfer im Timna-Tal. 4000 Jahre Bergbau und Verhuttung in der Arabah (Israel). En G. Conrad and B. Rothenberg (eds.): Der Anschnitt. Beiheft 1. Bochum.

ANTONOVA, E.V. 1998: Mesopotamiya na puti $k$ pervym gosudarstvam. Moscow. Vostochnaya Literatura.

AVILOVA, L.I. 1996: "Metall Mesopotamii v rannem i srednem bronzovom veke". Vestnik Drevnej Istorii 4: 68-81.

- 2001: "Drevnie bronzy Levanta". Rossiyskaya Arkheologiya 1: 15-26.

- 2003: "Zoloto i med' Troi”. Kratkie Soobshcheniya Instituta Arkheologii. Issue 215: 39-45.

- 2004a: "Drevnie bronzy Irana. Eneolit-srednii bronzovyi vek". Kratkie Soobshcheniya Instituta Arkheologii. Issue 216: 3-14.

- 2004b: "Iran i Mesopotamiya v eneolite - srednem bronzovom veke. Sravnitelnyi analiz proizvodstva metallicheskikh izdelii”. Evraziya. Etnokulturnoe vzaimodeistvie $i$ istoricheskie sud'by. Moscow. RSUH Publishers: 112-116.
- 2005: "Metall Zapadnoi Azii (eneolit - srednii bronzovyi vek". OPUS: Mezhdistsiplinarnye issledovaniya $v$ arkheologii. Issue 4: 11-28.

AVILOVA, L.I.; ANTONOVA, E.V. and TENEJSHVILI, T.O. 1999: "Metallurgicheskoe proizvodstvo v Yuzhnoi zone Tsirkumpontiiskoi metallurgicheskoi provintsii v epokhu rannei bronzy". Rossiyskaya Arkheologiya 1: 51-66.

AVILOVA, L.I. and CHERNYKH, E.N. 1989: "Malaya Aziya v sisteme metallurgicheskikh provintsii". Estestvennonauchnye metody $v$ arkheologii. Moscow. Nauka: 31-83.

AVILOVA, L.I. and ORLOVSKAYA, L.B. 2001: "Istoriko-metallurgicheskie i radiouglerodnye bazy dannykh po Tsirkumpontiiskoi metallurgicheskoi provintsii". Kratkie Soobshcheniya Instituta Arkheologii. Issue 211: 23-29.

AVILOVA, L.I. and TEREKHOVA, N.N. 2006: "Standartnye slitki metalla na Blizhnem Vostoke v epokhu eneolita - bronzovogo veka". Kratkie Soobshcheniya Instituta Arkheologii. Issue 220: 14-33.

BAR-ADON, P. 1980: The cave of the treasure. Jerusalem. Israeli Exploration Society.

ČERNYKH, E.N. and AVILOVA, L.I. 1996: "Circumpontic metallurgical province and metal from Troy". The workshops and posters of the XIII International Congress of Prehistoric and Protohistoric Sciences. Forli-Italia, 8-14 September, 2 Abstracts: 253-256.

ČERNYH, E.N.; AVILOVA, L.I.; BARCEVA, T.B.; ORLOVSKAJA, L.B. and TENEJSVILI, T.O. 1991: "The Circumpontic metallurgical province as a system". East and West 41 (1-4): 11-45.

CHERNYKH, E.N. 1966: Istoriya drevneyshei metallurgii Vostochnoi Evropy. Moscow. Nauka.

- 1971: "Earliest stage of metallurgy in Circumpontic zone". VIII Congres Internationale des sciences prehistoriques et protohistoriques. Belgrade: 1-12.

- 1992: Ancient metallurgy in the USSR. The Early Metal Age. Cambridge, Cambridge University Press.

CHERNYKH, E.N.; AVILOVA, L.I.; BARTSEVA, T.B.; LUNKOV, V.Yu, ORLOVSKAYA, L.B. and TENEJSHVILI, T.O. 1996: “Komp'yuternye programmy v istoriko-metallurgicheskikh issledovaniyakh laboratorii IA RAN". Komp'yutery $v$ arkheologii. Moscow. Institute of Archaeology Publishers: $56-65$.

CHERNYKH, E.N.; AVILOVA, L.I. and ORLOVSKAYA, L.B. 2002: "The Circumpontic metallurgical province: from unification to disintegration". Anatolian metal II / Ed. Ü. Yalçin. Der Anschnitt. Beiheft 15. Bochum: 83-100.

CIERNY, J. 2002: "Bronze Age tin mines in Central Asia". Kargalinskii Mezhdunarodnyi polevoi Simpozium-2002 "Drevneishie etapy gornogo dela i metallurgii v Severnoi Evrazii: Kargalinskii 
kompleks". Institute of Archaeology Publishers. Moscow: 76-78.

EATON, E.R. and McKERREL, H. 1976: "Near Eastern alloying and some textual evidence for the early use of arsenical copper". World Archaeology 8 (2): 169-191.

FRANGIPANE, M. 1985: "Early developments of metallurgy in the Near East". Studi di Paletnologia in onore di Salvatore M. Puglisi. Universita di Roma "La sapienza". Roma: 215-228.

GALE, N.H.; STOS-GALE, Z.A. and GILMORE, G.R. 1985: "Alloy types and copper sources of Anatolian copper alloy artefacts". Anatolian Studies XXXV: 143-173.

GILES, D.L. and KUJIPERS, E.P. 1974: "Stratiform copper deposit, Northern Anatolia, Turkey: Evidence for Early Bronze I (2800 B.C.) mining activity". Science 186: 823-825.

HERMANN, G. 1968: "Lapis lazuli: The early phases of its trade". Iraq 30: 21-57.

JESUS, P.S. de 1978: "Metal resources in ancient Anatolia". Anatolian Studies 23: 97-102.

KOHL, P. 1987: "The ancient economy, transferable technologies and the Bronze-Age world-system: A view from the Northeastern frontier of the Ancient Near East". En M. Rowlands, M.T. Larsen and K. Kristiansen (eds.): Centre and periphery in the Ancient world. Cambridge University Press. Cambridge: 13-24.

MELLAART, J. 1981: The prehistoric pottery from the Neolithic to the beginning of EB IV c. 7000-2500. British Archaeological Reports. 98. Oxford.

MADDIN, R.; STECH WHEELER, T. and MUHLY, J. 1980: "Distinguishing artifacts made of native copper". Journal of Archaeological Science 7: 211-225.

MOOREY, P.R.S. 1994: Ancient Mesopotamian materials and industries. The archaeological evidence. Clarendon Press. Oxford.

MUHLY, J.D. 1991: "The bronze metallurgy in Anatolia and the question of local tin sources". En E. Pernicka and G.A. Wagner (eds.): Archaeometry'90. Basle, Boston and Berlin: 209-220.

MUNCHAEV, R.M. 1975: Kavkaz na zare bronzovogo veka. Nauka. Moscow.

ÖZDOGAN, M. 2002: "The Bronze Age in Thrace in relation to the emergence of complex societies in Anatolia and in the Aegean". Anatolian metal II. Der Anschnitt. Beiheft 15. Bochum: 67-76.

PARZINGER, H. and BOROFFKA, N. 2003: Das Zinn der Bronzezeit in Mittelasien I. Die siedlungsarchäologischen Forschungen im Umfeld der Zinnlagerstätten. Archäologie in Iran und Turan. Bd. 5. Verlag Philipp von Zabern. Mainz am Rhein.

PERNICKA, E. 1995: "Gewinnung und Verbreitung der Metalle in prähistorischer Zeit”. Jahrbuch des
Römisch-Germanischen Zentralmuseums 37 (1): 21-129.

PIGOTT, V. 1999: “A heartland of metallurgy. Neolithic/Chalcolithic metallurgical origins on the Iranian Plateau". En A. Hauptmann, E. Pernicka, T. Rehren and Ü. Yalçin (eds.): The beginnings of metallurgy. Der Anschnitt. Beiheft 9. Bochum: 107-120.

PIOTROVSKY, Yu.Yu. 1996: "Izdeliya iz zolota i serebra na Severnom Kavkaze v epokhu rannei bronzy". Ermitazhnye chteniya pamyati B.B. Piotrovskogo. Ermitazh Publishers. St. Petersburg: 23-28.

PORADA, E.; HANSEN, D.P.; DUNHAM, S. and BABCOCK, S.H. 1992: "The chronology of Mesopotamia, ca. 7000-1600 B.C.”. En R. Ehrich (ed.): Chronologies in Old World archaeology. The University of Chicago Press. Chicago: 156-188.

POTTS, D.T. 1997: Mesopotamian civilization. The material foundations. Cornell University Press. Ithaca.

RYNDINA, N.V. 1998: Drevneishee metalloobrabatyvayushchee proizvodstvo Yugo-Vostochnoi Evropy. Editorial URSS. Moscow.

SHALEV, S. 1991: "Two different copper industries in the Chalcolithic culture of Israel'. Coll. Intern. Découverte du métal. Ed. Picard. Paris: 413-424.

SCHMIDT, E. 1937: Excavations at Tepe Hissar, Damghan, 1931-1933. University of Pennsylvania Press. Philadelphia.

TADMOR, M.; KEDEM, D.; BEGEMANN, F.; HAUPTMANN, A.; PERNICKA, E. and SCHMITTSTRECKER, S. 1995: "The Nahal Mishmar hoard from the Judean desert: Technology, composition and provenance". "Atiqot XXVII: 95-148.

TALLON, F. 1987: Métallurgie susienne I. De la fondation de Suse au XVIIIe siècle avant J.-C. I-II. Ministere de la culture et de la communication. Paris.

TOBLER, A.J. 1950: Excavations at Tepe Gawra. II. Philadelphia. University of Pennsylvania Press.

TOSI, M. 1974: "The problem of turquoise in protohistoric trade on the Iranian plateau". Studi di Paletnologia, Paleoantropologia, Paleontologia e Geologia del Quaternario 2: 147-162.

TRIFONOV, V.A. 1987: "Nekotorye voprosy peredneaziatskikh svyazei maikopskoi kultury". Kratkie Soobshcheniya Instituta Arkheologii. Issue 192: 18-26.

- 2000: "Kurgany maikopskogo tipa v severo-zapadnom Irane". Sud'ba uchenogo: K100-letiyu so dnya rozhdeniya B.A. Latynina. St.-Petersburg: 244-264.

VAVILOV, N.I. 1987: Proiskhozhdenie $i$ geografiya kulturnykh rastenii. Nauka. Leningrad.

VIRCHOW, R. 1891: "Analysen kaukasischer und assyrischer Bronzen”. Zeitschrift für Ethnologie-Verhandlungen: 354-369. 
VOIGT, M. and DYSON, R. 1992: "The chronology of Iran, ca. 8000-2000 B.C.”. En R. Ehrich (ed.): Chronologies in Old World archaeology. The University of Chicago Press. Chicago: 122-154.

WOOLLEY, C.L. 1955: Ur excavations. The early periods. Vol. IV. Oxford University Press. Oxford.
YENER, K.A. and ÖZBAL, H. 1987: "Tin in the Turkish Taurus mountains: the Bolkardag mining district". Antiquity 61: 220-226.

YULE, P. 1982: Tepe Hissar. Neolitische und kupferzeitliche Siedlung in Nordostiran. C.H. Beck. München. 